\title{
PENERAPAN ITERASI TENGAH BABILONIA DAN METODE BAKHSHALI DALAM PERHITUNGAN AKAR KUADRAT TIDAK SEMPURNA
}

\author{
ENDRO TRI SUSDARWONO \\ Universitas Peradaban, Jalan Raya Pagojengan KM 3 Paguyangan Brebes Jawa Tengah \\ saniscara99midas@gmail.com
}

First Received: 02-02-2021; Accepted: 06-04-2021

\begin{abstract}
Abstrak
Penelitian ini bertujuan meneliti mengenai efektivitas dan peningkatan motivasi penerapan iterasi tengah Babilonia dan metode Bakhshali dalam perhitungan akar kuadrat tidak sempurna. Pendekatan penelitian yang digunakan adalah kuantitatif. Pendekatan kuantitatif yang digunakan meliputi pengujian hipotesis atas tanda melalui kuesioner untuk menguji motivasi belajar matematika siswa setelah diberikan perlakuan metode iterasi tengah Babilonia dan India kuno (rumus Bakhshali). Adapun uji statistik lain yang digunakan adalah uji-t untuk sampel nonindependen dimaksudkan untuk melihat perbedaan setelah dilakukan treatment metode iterasi tengah Babilonia dan India kuno (rumus Bakhshali) melalui hasil tes. Kesimpulan hasil penelitian ini adalah berdasarkan pengujian hipotesis atas tanda diperoleh hasil bahwa dengan adanya penggunaan metode pembelajaran yakni berupa iterasi tengah Babilonia dan India kuno (rumus Bakhshali) untuk menghitung akar kuadrat tidak sempurna mampu meningkatkan motivasi belajar matematika. Sedangkan berdasarkan perhitungan uji-t sampel nonindependen didapatkan bahwa metode pembelajaran iterasi tengah Babilonia dan metode Bakhshali memiliki tingkat efektivitas untuk meningkatkan kemampuan matematika siswa dalam menghitung soal mengenai akar kuadrat tidak sempurna.
\end{abstract}

Kata kunci: Akar kuadrat tidak sempurna; Iterasi tengah Babilonia; Metode Bakhshali

\section{IMPLEMENTATION OF BABILONIA CENTRAL ITERATION AND THE BAKHSHALI METHOD IN CALCULATION OF IMPERFECT SQUARE ROOTS}

\begin{abstract}
This study aims to examine the effectiveness and motivation to increase the application of the Babylonian middle iteration and the Bakhshali method in calculating imperfect square roots. The research approach used is quantitative. The quantitative approach used includes testing the hypothesis of the sign through a questionnaire to test students' motivation to learn mathematics after being given the middle iteration method of Babylon and ancient India (Bakhshali formula). The other statistical test used is the t-test for non-independent samples intended to see the difference after treatment of the middle iteration method of Babylon and ancient India (Bakhshali formula) through the test results. The conclusion of the results of
\end{abstract}


this study is that based on hypothesis testing on the sign, it is found that the use of learning methods in the form of middle Babylonian and ancient India iterations (Bakhshali's formula) to calculate imperfect square roots can increase motivation to learn mathematics. Meanwhile, based on the calculation of the nonindependent sample t-test, it was found that the Babylonian middle iteration learning method and the Bakhshali method had a level of effectiveness to improve students' mathematical abilities in calculating problems regarding imperfect square roots.

Keywords: Imperfect square root; Middle Babylonian iteration; Bakhshali method

\section{PENDAHULUAN}

Matematika merupakan pelajaran yang diajarkan di setiap level sekolah, dari Sekolah Dasar hingga Universitas (Vilianti et al., 2008). Manthanein atau mathema adalah akar kata matematika yang berasal dari Bahasa Latin yang bermakna belajar atau hal yang dipelajari, sedangkan kata lain dari Bahasa Belanda yaitu wiskunde yang bermakna ilmu pasti (Siagian, 2017). Matematika yang merupakan salah satu alat dalam menyelesaikan suatu fenomena, biasanya berupa suatu rumusan. Artinya suatu fenomena dapat diselesaikan apabila sudah dirumuskan ke dalam bahasa matematika.

Keterkaitan erat antara pendidikan dan matematika adalah terutama dalam bidang perkembangan ilmu pengetahuan dan teknologi. Matematika merupakan cabang ilmu penting yang perlu diberikan pemahamann dan penguasaan terhadap semua lapisan masyarakat utamanya di sekolah (Dila \& Zanthy, 2020). Pemahaman dan penguasaan terhadap matematika itu harus diawali dari yang mudah, sedang, hingga sulit dikarenakan matematika merupakan ilmu terstruktur, dalam matematika terdapat banyak konsep yang saling terkait antara konsep yang satu dengan yang lainnya. Koneksi matematis harus dimiliki siswa dalam memahami pemahaman konsep secara mendalam (Nurhayati et al., 2020). Terkait dengan pemahaman suatu konsep dalam matematika, akal atau rasio merupakan modal dasar dalam menguasai matematika disebabkan bidang ilmu ini pada hakikatnya merupakan suatu ilmu yang berhubungan benda-benda dalam pikiran yang abstrak atau matematika memiliki objek kajian yang abstrak (Prasetya \& Ahmadi, 2015). Salah satu contoh objek kajian abstrak yang dimaksud adalah ketika siswa diberikan suatu perhitungan terkait dengan akar kuadrat.

Perhitungan akar kuadrat adalah salah satu prosedur algoritma tertua dalam matematika. Orang Babilonia merancang algoritma berulang yang luar biasa untuk kalkulasi akar kuadrat di sekitar 1500 SM. Algoritma ini mudah dipahami dan dapat dilakukan dengan cepat, menghasilkan akurasi sekitar 26 digit desimal hanya dalam lima iterasi (Osler, 1999). Metode Babilonia adalah salah satu metode tertua dari pendekatan akar kuadrat, dan masih merupakan 
alat yang berharga untuk memahami pengembangan dan fungsi metode penentuan nilai akar kuadrat (Johnson, 2017). Sebelum melakukan perhitungan terkait akar kuadrat dengan iterasi tengah Babilonia, perlu dipahami mengenai iterasi. Iterasi adalah proses perhitungan sederhana berulang-ulang yang biasanya dipakai untuk program komputer (Thiemann, 2013). Ada banyak iterasi yang mungkin untuk menghitung akar kuadrat misalnya iterasi interval tengah, iterasi interpolasi linier dan sebagainya. Apabila nilai awal yang diambil cukup dekat, iterasi Babilonia biasanya hanya butuh satu atau dua langkah saja untuk mendapatkan akar yang cukup dekat dengan akar sebenarnya (Fowler \& Robson, 1998).

Selain metode perhitungan akar kuadrat melalui metode iterasi tengah Babilonia, dikenal juga metode Bakhshali yang merupakan metode India kuno. Metode penggalian akar kuadrat dari bilangan non-kuadrat yang diperlihatkan dalam teks ini sangat menarik. "Dalam kasus nonkuadrat (bilangan), kurangi bilangan kuadrat terdekat; bagi sisanya dengan dua kali (akar dari bilangan itu). Setengah kuadrat dari (yaitu pecahan yang baru saja diperoleh) dibagi dengan jumlah akar dan pecahan dan pengurangan; (ini akan menjadi nilai perkiraan dari akar) dikurangi kuadrat dari suku terakhir" (Sansthana, 1979). Akar kuadrat dari bilangan apa pun diperoleh dalam satu langkah yang mengurangi iterasi. Metode Bakhshali digunakan untuk menemukan akar kuadrat proksimal yang dijelaskan dalam naskah matematika India kuno yang disebut manuskrip Bakhshali (Banerjee et al., 2015).

Dunia Matematika sebenarnya begitu luas. Bahkan teknik ilmu hitung dasar semacam KaBaTaKur (Kali Bagi Tambah Kurang) sebenarnya banyak macamnya. Sekolah biasanya hanya mengambil satu cara dan mengabaikan cara yang lain (Arryawan, 2011). Dari beberapa metode tersebut pada dasarnya dapat diterapkan dengan tujuan yang sama, yaitu menentukan akar-akar kuadrat dengan error yang paling kecil (Iqbal, 2014).

Berdasarkan latar belakang di atas, penelitian ini bertujuan untuk mendeskripsikan penerapan iterasi tengah Babilonia dan metode Bakhshali dalam perhitungan akar kuadrat tidak sempurna. Penelitian dilakukan didasarkan pada kemudahan atau kecepatan terhadap metode atau teknik yang dimaksud.

\section{METODE PENELITIAN}

Metode penelitian adalah cara alamiah untuk memperoleh data dengan kegunaan dan tujuan tertentu (Lestari \& Yudhanegara, 2015). Dalam penelitian ini metode penelitian yang digunakan adalah eksperimen. Sedangkan pendekatan dalam penelitian ini yang digunakan adalah kuantitatif. Pendekatan kuantitatif yang digunakan meliputi pengujian hipotesis atas 
tanda melalui kuesioner untuk menguji motivasi belajar matematika siswa setelah diberikan perlakuan metode iterasi tengah Babilonia dan India kuno (rumus Bakhshali). Pengujian hipotesis atas tanda digunakan untuk menganalisis dampak yang timbul karena stimulus yang diberikan. Adapun uji statistik lain yang digunakan adalah uji-t untuk sampel nonindependen dimaksudkan untuk melihat perbedaan setelah dilakukan treatment metode iterasi tengah Babilonia dan India kuno (rumus Bakhshali) melalui hasil tes.

\section{Desain Penelitian}

Desain penelitian adalah keseluruhan dari perencanaan untuk menjawab pertanyaan penelitian dan mengantisipasi beberapa kesulitan yang mungkin timbul selama proses penelitian. Hal ini penting karena desain penelitian merupakan strategi untuk mendapatkan data yang dibutuhkan untuk keperluan pengujian hipotesis atau untuk menjawab pertanyaan penelitian, dan sebagai alat untuk mengontrol variabel yang berpengaruh dalam penelitian (Sugiono, 2010).

Desain kuantitatif yang akan digunakan dalam penelitian ini berupa desain penelitian eksperimen The one-group pretest-posttest design. Desain ini digunakan karena dalam penelitian ini terdapat suatu kelompok yang diberi perlakuan (treatment) yaitu siswa Sekolah Dasar kelas 6, kemudian bermaksud untuk membandingkan keadaan sebelum dengan sesudah diberi perlakuan. Dengan demikian, hasil perlakuan dapat diketahui lebih akurat. Paradigma dalam penelitian diilustrasikan melalui Gambar 1.

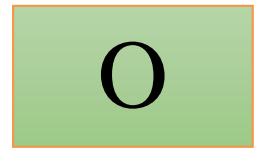

Pretes untuk mengukur kemampuan awal kemampuan matematika

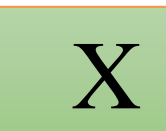

Metode Iterasi Tengah

Babilonia dan India Kuno

(Rumus Bakhshali)

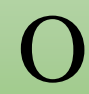

Postes untuk mengukur kemampuan akhir kemampuan matematika

Keterangan:

Gambar 1. The one-group pretest-posttest design

$\mathrm{X}=$ perlakuan/treatment yang diberikan (variabel independen)

$\mathrm{O}=$ pretes dan postes (variabel dependen yang diobservasi)

Teknik sampling yang digunakan untuk desain ini adalah purposive sampling. Purposive sampling adalah teknik penentuan sampel dengan pertimbangan tertentu. Pertimbangan dalam mengambil sampling penelitian dimaksudkan untuk meneliti siswa Sekolah Dasar kelas 6 (enam) di Kabupaten Pemalang disebabkan bahwa Siswa Sekolah Dasar kelas 6 dipilih terkait tema hitung cepat dalam menghadapi Ujian Nasional. 


\section{HASIL DAN PEMBAHASAN}

Penelitian ini bertujuan untuk menguji peningkatan motivasi belajar siswa dan perbedaan efektivitas model/metode pembelajaran yakni berupa iterasi tengah Babilonia dan India kuno (rumus Bakhshali) dalam meningkatkan kemampuan untuk menghitung akar kuadrat tidak sempurna matematika anak tingkat kelas 6 Sekolah Dasar. Pengujian yang digunakan adalah pengujian hipotesis atas tanda, uji-t untuk sampel nonindependen. Sampel nonindependen adalah sampel yang dibentuk melalui penjodohan. Sampel penjodohan yang sempurna adalah kelompok sama yang dipakai pada waktu yang tidak bersamaan (satu kelompok yang menerima dua treatment pada waktu yang berbeda). Individu anggota sampel dalam penelitian ini tidak dipilih secara random. Situasi untuk dapat menetapkan signifikansi perbedaan antara mean kelompok tidak diambil secara random karena individu-individu kelompok yang dipasangkan dipilih atas dasar satu karakteristik. Treatment atau perlakuan diberikan dalam waktu 30 hari. Kemudian dilakukan pembandingan antara nilai pretest dan postestnya, pretest dilakukan sebelum diberikan perlakuan berupa teknik hitung akar kuadrat dengan iterasi tengah Babilonia dan akar kuadrat ala India kuno (Rumus Bakhshali), postest diberikan setelah perlakuan diberikan.

Berikut adalah manipulasi/perlakuan yang diberikan terhadap variabel yang diteliti berupa kemampuan teknik hitung akar kuadrat dengan iterasi tengah Babilonia dan akar kuadrat ala India kuno (Rumus Bakhshali) yang diberikan dalam pembelajaran matematika untuk siswa Sekolah Dasar (SD) untuk selanjutnya diambil nilai posttest.

\section{Menghitung Akar Kuadrat dengan Iterasi Tengah Babilonia}

Pada pembahasan kali ini kita akan mempelajari jurus hitung lain yang diturunkan dari Metode Ilmu Hitung Babilonia. Langkah-langkah mencari akar kuadarat ala Bangsa Babilonia: Anggap saja kita ingin menghitung akar kuadrat dari A.

1. Pertama: menentukan nilai akar dari A. Anggap saja kita namakan itu $x$. Kita bisa memilih $x$ sembarang angka sebagai akar A, tetapi jika perkiraan awal ini "tidak terlalu ngawur" maka proses perhitungannya akan lebih cepat. Misalnya jika kita ingin menghitung berapa akar kuadrat dari 500? Tidak masalah jika Anda mengisikan misalnya harga awal 40, tetapi akan lebih cepat perhitungannya jika anda isikan misalnya 20 , karena $20 \times 20$ $=400$ cukup dekat dengan 500. Atau akan lebih cepat lagi perhitungannya jika anda isikan 22, karena 22 kali $22=484$ lebih dekat ke 500 . 
2. Kedua: hitung nilai dari A dibagi angka tebakan atau A dibagi $x$. Bila kita menghitung akar 500, dan memberi nilai $x=20$ maka berarti kita harus menghitung 500/20. Anggap saja kita namakan itu $y$.

3. Ketiga: hitung nilai tengah atau rata-rata dari $x$ dan $y$. Akar kuadrat dari A adalah pendekatan dari nilai tengah tersebut.

Berikut soal yang diberikan ke siswa dan contoh jawaban pada Gambar 2, setelah melalui perlakuan atau stimulus teknik hitung akar kuadrat dengan iterasi tengah Babilonia. Dengan teknik hitung akar kuadrat dengan iterasi tengah Babilonia, hitunglah:

1. $\sqrt{20}=$ ?

2. $\sqrt{40}=$ ?

3. $\sqrt{200}=$ ?

4. $\sqrt{150}=$ ?

5. $\sqrt{60}=$ ?
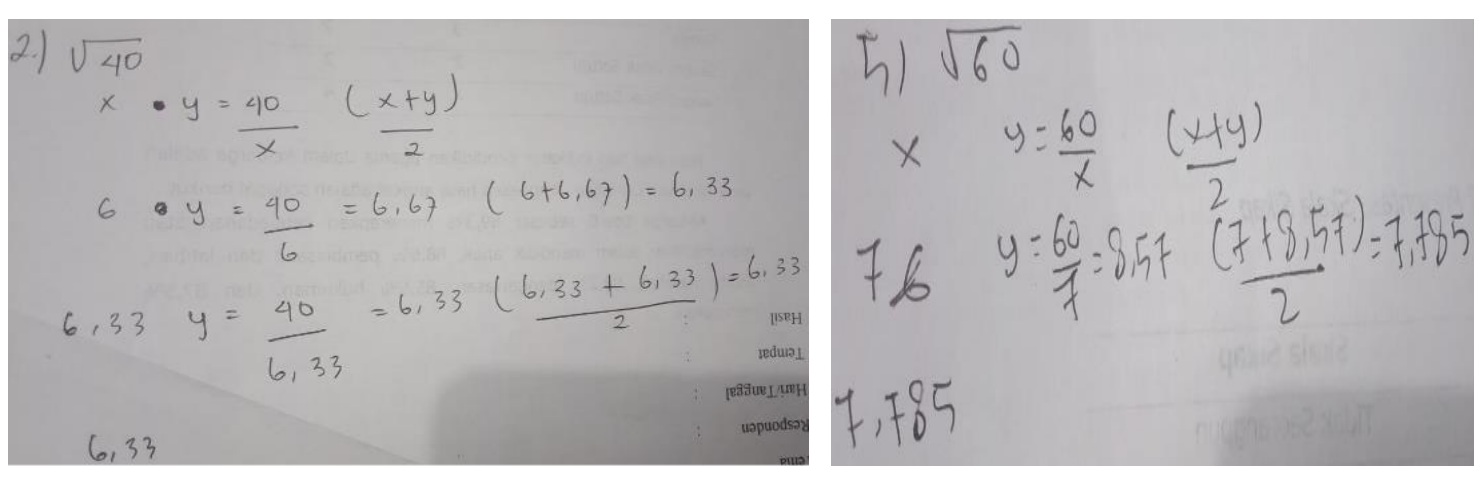

Gambar 2. Contoh jawaban siswa menghitung akar kuadrat dengan iterasi tengah Babilonia

\section{Menghitung akar kuadrat ala India Kuno (Rumus Bakhshali)}

Jika Bangsa Babilonia memiliki teknik iterasi untuk menghitung akar kuadrat, bangsa India kuno memiliki rumus yang menarik untuk menghitung akar kuadrat. Rumus yang ditulis berikut ini berasal dari naskah Bakhshali, naskah matematika India kuno yang ditulis di kulit pohon ditemukan tahun 1881 di desa Bakshali.

Langkah menghitung akar kuadrat dengan Rumus Bakhshali adalah sebagai berikut:

$$
\sqrt{A=?}
$$

1. Langkah Pertama: Tetapkan asumsi awal nilai akar $(x)$. Hitung nilai $x$

2. Langkah Kedua: Hitung nilai Sisa $(\mathrm{S})=\mathrm{A}-x^{2}$

3. Langkah Ketiga: Hitung Bagi $(B)=\frac{s}{2 \cdot x}$, Hitung $\mathrm{B}^{2}$

4. Langkah Keempat: Hitung Jumlah $(\mathrm{J})=x+\mathrm{B}$ 
5. Langkah Kelima: $\sqrt{A} \approx J-\frac{B^{2}}{2 \cdot x}$

Apabila diinginkan metode Bakhshali juga bisa diulang untuk menghasilkan ketelitian yang lebih tinggi, dengan memasukkan hasil akhir menjadi nilai awal $x$. Untuk perhitungan manual, sepanjang harga awalnya cukup baik, biasanya cukup menghitung satu kali saja.

Berikut soal yang diberikan ke siswa dan contoh jawaban siswa pada Gambar 3. Setelah melalui perlakuan atau stimulus teknik hitung akar kuadrat ala India Kuno (Rumus Bakhshali). Dengan teknik hitung akar kuadrat ala India kuno (Rumus Bakhshali), t hitunglah akar kuadrat berikut ini:
1. $\sqrt{30}=$ ?
2. $\sqrt{40}=$ ?
3. $\sqrt{50}=$ ?
4. $\sqrt{150}=$ ?
5. $\sqrt{60}=$ ?
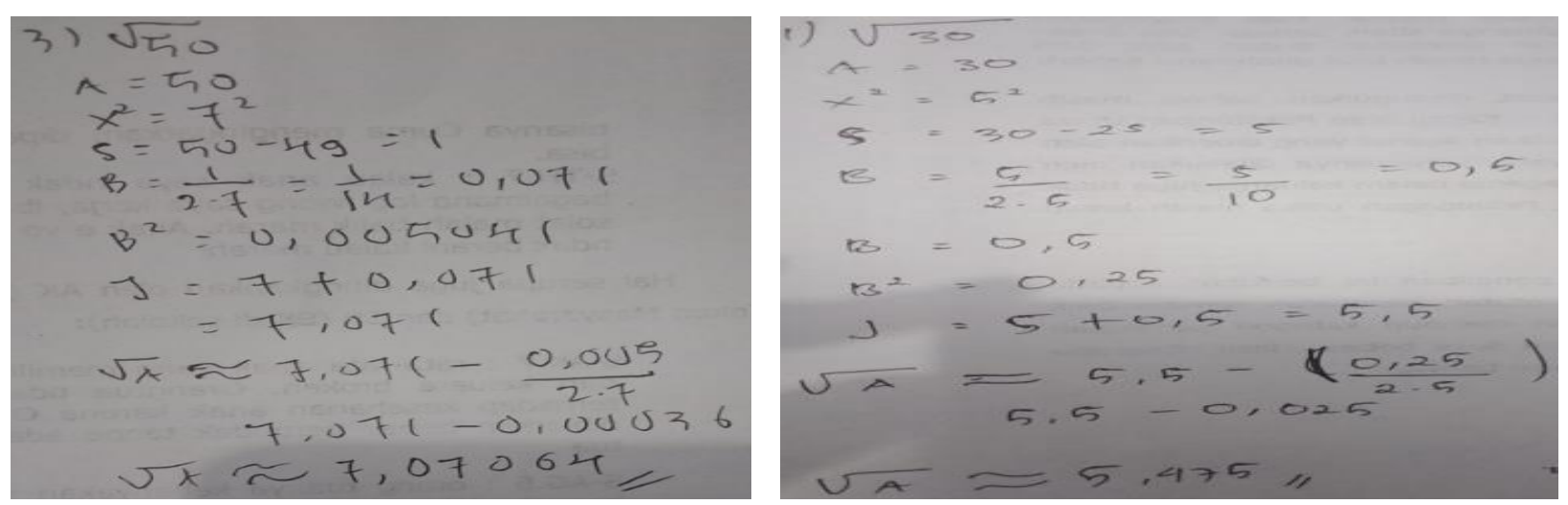

Gambar 3. Contoh jawaban siswa teknik hitung akar kuadrat ala India kuno (Rumus Bakhshali)

Berdasarkan pengujian hipotesis atas tanda dari penyebaran kuesioner yang telah dilakukan, diperoleh informasi mengenai bagaimana motivasi siswa terkait kemampuan menyelesaikan soal akar kuadrat tidak sempurna.

Tabel 1. Pengujian hipotesis atas tanda

\begin{tabular}{ccc}
\hline Nomor & Dampaknya Terhadap Motivasi & Tanda \\
\hline 1 & Meningkat & + \\
2 & Meningkat & + \\
3 & Meningkat & + \\
4 & Meningkat & + \\
5 & Meningkat & + \\
6 & Meningkat & + \\
7 & Menurun & - \\
8 & Meningkat & + \\
9 & Meningkat & + \\
10 & Meningkat & + \\
\hline
\end{tabular}


Dari tampilan data yang tercantum dalam tabel tersebut, beberapa langkah pengujian hipotesis yang harus dilakukan di antaranya adalah hal yang dijelaskan sebagai berikut.

Merumuskan hipotesis nihil dan hipotesis alternatif, setelah kita melihat tampilan data dalam tabel terlihat bahwa jumlah tanda positif lebih besar, yakni 9. Dengan demikian, mengingat bahwa jumlah selisih positif lebih besar, pengujian hipotesis yang diberlakukan adalah pengujian sisi kanan. Hipotesis nihil pada intinya menyatakan bahwa metode pembelajaran yakni berupa iterasi tengah Babilonia dan India kuno (rumus Bakhshali) tidak dapat meningkatkan motivasi siswa. Sedangkan hipotesis alternatif menyatakan bahwa metode pembelajaran yakni berupa iterasi tengah Babilonia dan India kuno (rumus Bakhshali) dapat meningkatkan motivasi siswa. Karena itulah, dalam kasus ini hipotesis nihil dan hipotesis alternatif dirumuskan secara simbolis sebagai berikut:

$\mathrm{H}_{0}: \mathrm{P}_{\text {motivasi belajar meningkat }}=\mathrm{P}_{\text {motivasi belajar tidak meningkat }}$

$\mathrm{H}_{\mathrm{a}} \quad \mathrm{P}_{\text {motivasi belajar meningkat }}>\mathrm{P}_{\text {motivasi belajar tidak meningkat }}$

Menentukan taraf signifikansi tertentu, berkaitan dengan ilustrasi kasus ini, taraf signifikansi yang diberlakukan adalah $5 \%$ atau 0,05 . Dalam tabel chi-kuadrat, nilai chi-kuadrat untuk derajat kebebasan sebesar 1 dan taraf signifikansi 0,05 adalah 3,841.

Merumuskan kriteria pengujian, untuk kasus ini, pengujian hipotesis yang diberlakukan adalah pengujian sisi kanan. Maka, kriteria pengujian yang diberlakukan dalam kasus ini adalah bahwa hipotesis nihil diterima apabila

$$
x^{2} \leq 3,841
$$

Sedangkan hipotesis nihil ditolak jika

$$
x^{2}>3,841
$$

Menghitung nilai chi-kuadrat, dalam tabel, jumlah selisih atau tanda positif $\left(\mathrm{n}_{1}\right)$ adalah 9 dan jumlah selisih atau tanda negatif $\left(\mathrm{n}_{2}\right)$ adalah 1 . Sehingga, berdasarkan rumus untuk menghitung nilai chi-kuadrat yang telah ditampilkan di rumus, nilai chi-kuadratnya adalah sebesar

$$
\begin{gathered}
x^{2}=\frac{\left[\left(n_{1}-n_{2}\right)-1\right]^{2}}{n_{1}+n_{2}} \\
\frac{[(9-1)-1]^{2}}{(9+1)}=\frac{49}{10}=4,9
\end{gathered}
$$

Merumuskan kesimpulan akhir, berdasarkan atas hasil perhitungan di atas, nilai chikuadrat adalah 4,9. Nilai chi-kuadrat itu lebih besar daripada nilai chi-kuadrat dalam tabel sebesar 3,841. Dengan demikian, hipotesis nihil yang menyatakan bahwa metode pembelajaran yakni berupa iterasi tengah Babilonia dan India kuno (rumus Bakhshali) ini tidak dapat 
meningkatkan motivasi belajar siswa ditolak. Sebaliknya, hipotesis alternatif yang menyatakan bahwa metode pembelajaran yakni berupa iterasi tengah Babilonia dan India kuno (rumus Bakhshali) ini dapat meningkatkan motivasi belajar bisa diterima.

Uji-t untuk sampel nonindependen digunakan untuk melihat apakah dua kelompok nilai (pretest dan posttest) tersebut berbeda secara signifikan. Untuk menetapkan signifikansi perbedaan antara mean kelompok nilai tersebut perlu dihitung koefisien korelasi antara skor pretest dan posttest.

Rumus uji-t untuk sampel nonindependen:

$$
\begin{gathered}
t=\frac{M_{D}}{\sqrt{\frac{\sum D^{2}-\frac{\left(\sum D\right)^{2}}{n(n-1)}}{n(n-1)}}} \\
d f=n-1
\end{gathered}
$$

Tingkat kebebasan dicari dengan rumus $\mathrm{n}-1$, jumlah pasangan dikurangi satu. Apabila nilai $\mathrm{t}$ hitung sama dengan atau lebih besar dibanding harga t tabel, peneliti menolak hipotesis nol; mean-mean berbeda secara signifikan pada suatu tingkat signifikansi yang dipilih.

Berikut data nilai pretest dan posttest dari hasil penelitian siswa disajikan melalui Tabel 2 berikut.

Tabel 2. Nilai hasil pretest dan posttest siswa

\begin{tabular}{cc}
\hline Nilai pretest & Nilai posttest \\
\hline 2 & 5 \\
3 & 6 \\
3 & 7 \\
4 & 3 \\
4 & 7 \\
4 & 6 \\
5 & 8 \\
5 & 8 \\
6 & 7 \\
6 & 9 \\
\hline
\end{tabular}

Perhitungan uji-t untuk sampel nonindependen dalam penelitian ini. Rumus yang digunakan sesuai dengan formula 1. D adalah sImbol yang baru; D singkatan dari "defference." D adalah beda antara skor pasangan-pasangan yang dijodohkan. Jadi, masing-masing D sama dengan $\mathrm{M}_{1}-\mathrm{M}_{2}$. Untuk data di atas beda skor pasangan yang pertama adalah $2-5=-3$.

Berikut disajikan dalam Tabel 3, yang merupakan tabel kerja. Setelah menghitung D setiap pasangan nilai dan sekaligus menghitung kuadrat dari D, jumlah dan mean dari D (MD) dapat kita peroleh. Mean dari D dihitung dengan cara yang sama untuk mean yang lain, dengan menambahkan masing-masing D dan membagi dengan jumlah individu. 
Tabel 3. Tabel kerja Uji-t untuk sampel nonindependen

\begin{tabular}{cccc}
\hline $\mathbf{X}_{\mathbf{1}}$ & $\mathbf{X}_{\mathbf{2}}$ & $\mathbf{D}$ & $\mathbf{D}^{\mathbf{2}}$ \\
\hline 2 & 5 & 3 & 9 \\
3 & 6 & 3 & 9 \\
3 & 7 & 4 & 16 \\
4 & 3 & -1 & 1 \\
4 & 7 & 3 & 9 \\
4 & 6 & 2 & 4 \\
5 & 8 & 3 & 9 \\
5 & 8 & 3 & 1 \\
6 & 7 & 1 & 9 \\
6 & 9 & 3 & $\Sigma \mathrm{D}^{2}=76$ \\
& & $\Sigma \mathrm{D}=24$ & \\
\hline
\end{tabular}

$M D=\frac{\sum D}{n}$

$M D=\frac{24}{10}$

$M D=2,4$

Setelah semua komponen didapatkan, maka substitusikan bilangan-bilangan tersebut pada rumus t.

$$
\begin{aligned}
t & =\frac{M_{D}}{\sqrt{\frac{\sum D^{2}-\frac{\left(\sum D\right)^{2}}{n(n-1)}}{n(4)}}} \\
& =\frac{2,4}{\sqrt{\frac{76-\frac{24^{2}}{10}}{10(10-1)}}} \\
& =\frac{2,4}{\sqrt{\frac{76-57,6}{10(9)}}} \\
& =\frac{2,4}{\sqrt{\frac{18,4}{90}}} \\
& =\frac{2,4}{\sqrt{0,204}}=5,308
\end{aligned}
$$

Dari perhitungan di atas diperoleh hasil, t-hitung $=5,308$. Untuk menggunakan tabel maka df ditentukan terlebih dahulu. Untuk uji t sampel nonindependen rumus tingkat kebebasan (df) adalah $\mathrm{n}-1$, jumlah pasangan dikurangi $1, \mathrm{df}=10-1=9$. Jadi dari tabel untuk $\alpha=0,05$; df $=9$ didapatkan nilai $\mathrm{t}$ tabel 2,262. Karena 5,308 $\geq 2,262$, sehingga hipotesis nol ditolak dan 
hipotesis alternatif diterima yang berarti bahwa kedua kelompok nilai (pretest dan posttest) berbeda secara signifikan.

\section{SIMPULAN}

Berdasarkan hasil penelitian yang telah diuraikan, maka kesimpulan dari penelitian eksperimen ini adalah berdasarkan pengujian hipotesis atas tanda diperoleh hasil bahwa dengan adanya penggunaan metode pembelajaran yakni berupa iterasi tengah Babilonia dan India kuno (rumus Bakhshali) untuk menghitung akar kuadrat tidak sempurna mampu meningkatkan motivasi belajar matematika untuk menghitung akar kuadrat tidak sempurna siswa. Sedangkan berdasarkan perhitungan uji-t sampel nonindependen maupun uji beda t-test dengan sampel berhubungan SPSS, didapatkan bahwa hipotesis nol ditolak dan menerima hipotesis alternatif, dimana dinyatakan bahwa kedua kelompok berbeda secara signifikan. Dengan ini menunjukkan bahwa metode pembelajaran yakni berupa iterasi tengah Babilonia dan India kuno (rumus Bakhshali) memiliki tingkat efektivitas untuk meningkatkan kemampuan matematika siswa dalam menghitung soal mengenai akar kuadrat tidak sempurna.

\section{DAFTAR PUSTAKA}

Arryawan, E. (2011). Matematika Yin Yang (Jurus Hitung Sakti Dari Barat dan Timur) Jakarta: PT Elex Media Komputindo.

Banerjee, Arindam, Ghosh, Aniruddha, \& Das, Mainuck. (2015). High Performance Novel Square Root Architecture Using Ancient Indian Mathematics for High Speed Signal Processing. Advances in Pure Mathematics, 5(1), 428-441.

Dila, Oki Ratna \& Zanthy, Luvy Sylviana. (2020). Identifikasi Kesulitan Siswa dalam Menyelesaikan Soal Aritmatika Sosial. Teorema: Teori dan Riset Matematika, 5(1), 1726.

Fowler, D. \& Robson, E. (1998). Square root approximations in Old Babylonian mathematics: YBC 7289 in context. Historia Mathematica, 25(4), 366-378.

Iqbal, Muhammad. (2014). Implementasi Algoritma Pencarian Akar Kuadrat Bilangan Positif Skripsi: Universitas Brawijaya.

Johnson, Gersham. (2017). The Babylonian Method and Its Properties file:///C:/Users/ASUS/Downloads/johnson.pdf diakses tanggal 24 November 2020 pukul 11.00 
Lestari, Karunia Eka \& Yudhanegara, Mokhammad Ridwan. (2015). Penelitian Pendidikan Matematika. Bandung: PT Refika Aditama.

Nurhayati, Yanti et al. (2020). Integrasi Contextual Teaching Learning (CTL) dengan Geogebra: Dapatkah Meningkatkan Kemampuan Koneksi Matematis Siswa?. Teorema: Teori dan Riset Matematika, 5(1), 27-34.

Prasetya, J. T., \& Ahmadi, A. (2015). Strategi belajar mengajar. Bandung: CV.

Sansthana, Ratna Kumari Svadhyaya. (1979). The Bakhshali Manuscript. Allahabad: Arvind Printers.

Siagian, M. D. (2017). Pembelajaran Matematika Dalam Persfektif Konstruktivisme. NIZHAMIYAH (Jurnal Pendidikan Islam Dan Teknologi Pendidikan), 7(2), 61-73.

Sugiyono. (2010). Metode Penelitian Bisnis (Pendekatan Kuantitatif, Kualitatif dan R\&D). Bandung: Alfabeta.

Thiemann, R. (2013). Computing Square Roots using the Babylonian Method Archive of Formal Proofs. Http://Afp. Sf. Net/Entries/Sqrt_Babylonian. Shtml.

Thomas J. Osler. (1999). Extending The Babylonian Algorithm. Mathematics and Computer Education, 33(2), 120-128.

Vilianti, Y., Pratama, F., \& Mampouw, H. (2018). Description of the ability of social arithedical stories by study problems by students VIII SMP reviewed from the polya stage. International Journal of Active Learning, 3(1), 23-32. 